\title{
PENANGANAN TINDAK PIDANA PERDAGANGAN ORANG DI PROVINSI MALUKU
}

\author{
Deassy J.A. Hehanussa ${ }^{1}$, Denny Latumaerissa ${ }^{2}$, Iqbal Taufik ${ }^{3}$ \\ ${ }^{1}$ Fakultas Hukum, Universitas Pattimura \\ email: deassyhehanussa@gmail.com \\ ${ }^{2}$ Fakultas Hukum, Universitas Pattimura \\ email: dino_elbarca@yahoo.com \\ ${ }^{3}$ Fakultas Hukum, Universitas Pattimura \\ email: Iqbal.taufik87@gmail.com
}

\begin{abstract}
ABSTRAK
Perdagangan orang yang dikenal dengan istilah Human Trafficking merupakan kejahatan yang sangat sulit untuk diberantas dan disebut-sebut oleh masyarakat internasional sebagai bentuk perbudakan masa kini dan pelanggaran terhadap hak asasi manusia modern. Kejahatan ini terus berkembang secara nasional maupun internasional yang dapat dikualifikasi sebagai kejahatan transnasional (lintas Negara). Maluku merupakan daerah yang kaya akan sumber daya alamnya ternyata tidak berbanding lurus dengan taraf hidup ekonomi penduduknya. Hal ini berimplikasi pada maraknya kejahatan yang terjadi di Maluku, salah satunya adalah tindak pidana perdagangan orang. Tujuan dari penelitian ini adalah untuk mengetahui modus operandi tindak pidana perdagangan orang di Maluku serta mengetahui kendala dalam penanganan tindak pidana perdagangan orang di Maluku. Metode penelitian yang digunakan adalah penelitian yuridis empiris, dimana peneliti melakukan wawancara dengan para penyidik yang menangani tindak pidana perdagangan orang baik di Polda Maluku, Polres P. Ambon dan P.P Lease, serta Polres Kep. Aru. Berdasarkan hasil penelitian didapati bahwa modus operandi yang dilakukan yaitu dengan merekrut, menampung, yang didahului oleh janji untuk mempekerjakan korban. Kendala dalam penangananan TPPO di Maluku yaitu: Budaya konsumtif dan hedonisme di masyarakat, Kemajuan Teknologi dan Informasi, Adanya bekingan dari segelintir orang yang memiliki kekuasaan, Biaya pemulangan korban TPPO ke daerah asal minim; Ketersediaan rumah singgah bagi korban TPPO belum merata di Wilayah Maluku, terbatasnya anggaran, minimya pemahaman masyarakat tentang TPPO.
\end{abstract}

Kata Kunci : Penanganan, perdagangan orang, Provinsi Maluku

\section{PENDAHULUAN}

Perdagangan orang atau perdagangan manusia di Indonesia sangat memprihatinkan. Hal ini terbukti hampir setiap hari orang bisa menyaksikan lewat media massa akan tindakan dan korban perdagangan orang ini (Hardum, 2016). Perdagangan orang yang dikenal dengan istilah Human Trafficking merupakan kejahatan yang sangat sulit untuk diberantas dan disebut-sebut oleh masyarakat internasional sebagai bentuk perbudakan masa kini dan pelanggaran terhadap hak asasi manusia modern. Dikatakan demikian karena perdagangan orang adalah bentuk modern dari perbudakan manusia (Modern Day Slavery) dan merupakan salah satu bentuk perlakuan terburuk dari pelanggaran harkat dan martabat manusia (Indonesia-IOM, 2009).

Kejahatan ini terus berkembang secara nasional maupun internasional sehingga dapat dikualifikasi sebagai kejahatan transnasional (lintas negara). Selain itu memiliki keterkaitan dengan kejahatan terorganisir serta ancaman-ancaman keamanan yang sangat serius seperti perdagangan obatobatan terlarang dan senjata, menjadi semakin jelas. Disamping kaitannya dengan keprihatinan kesehatan masyarakat yang serius, karena banyak korban mengidap penyakit, baik akibat kondisi hidup yang miskin maupun akibat dipaksa melakukan hubungan seks, dan diperdagangkan ke komunitas-komunitas baru. Persoalan ini menyangkut tindakan yang melanggar harkat dan martabat manusia dan bertentangan dengan peraturan yang berlaku.

Disisi lain kejahatan tersebut merupakan salah satu bentuk pelanggaran terhadap hak asasi manusia. Perdagangan orang telah meluas dalam bentuk jaringan kejahatan yang terorganisasi dan 
tidak terorganisasi, baik bersifat antar negara maupun dalam negeri, sehingga menajadi ancaman terhadap masyarakat,bangsadan Negara, serta terhadap norma-norma kehidupan yang dilandasi penghormatan terhadap hak asasi manusia. (Munthe, 2015). Korban diperdagangkan tidak hanya untuk tujuan pelacuran atau bentuk eksploitasi lainnya, tetapi juga mencakup bentuk eksploitasi lain, misalnya kerja paksa atau pelayanan paksa, perbudakan atau praktek serupa perbudakan. (Heni, 2013)

Tindak pidana perdagangan orang sebagai terjemahan kata "human trafficking" dalam Bahasa Inggris yang menjadi standar internasional untuk mengidentifikasi segala kegiatan ilegal yang berkaitan dengan perpindahan atau transfer manusia dari suatu negara ke negara lain dengan tujuan memperoleh keuntungan secara komersial dengan cara mengeksploitasi sumber daya manusia tersebut tanpa mengindahkan atau menghormati hak-hak asasi manusia. (Farhana, 2010). Trafficking atau perdagangan orang seolah merupakan sebuah keprihatinan sosial sebab mayoritas korban perdagangan orang tersebut ialah perempuan dan anak-anak. Perkembangan teknologi informasi, komunikasi dan transportasi memberikan dampak semakin berkembang modus kejahatannya dimana beroperasinya sering secara tertutup dan bergerak di luar hukum. Pelaku perdagangan orangpun dengan cepat berkembang menjadi sindikasi lintas batas negara dengan cara kerja yang mematikan. Penanggulangan kejahatan tersebut dengan menggunakan hukum pidana merupakan bagian kebijakan kriminal. Menurut Marc Ancel, kebijakan kriminal adalah suatu usaha yang rasional dari masyarakat dalam menanggulangi kejahatan. (Muladi \& Arief, 2010). Penanggulangan kejahatan tersebut adalah dalam rangka untuk mencapai tujuan akhir dari kebijakan kriminal itu sendiri yaitu memberikan perlindungan kepada masyarakat dalam rangka untuk mencapai kesejahteraan bagi masyarakat. (Arief, 2010).

Praktek perdagangan orang yang paling dominan berada di sektor jasa prostitusi, dimana kebanyakan korbannya adalah anak-anak dan perempuan. Secara garis besar permasalahan perdagangan orang yang sering terjadi di Indonesia memiliki tiga bentuk yaitu: (1) Buruh Migran; (2) Pembantu Rumah Tangga; (3) Pekerja Seks Komersial

Di samping itu, dalam berbagai studi dan laporan dari NGO menyatakan bahwa Indonesia merupakan daerah sumber dalam perdagangan orang, di samping juga sebagai transit dan penerima perdagangan orang (NGO, 2005). Berbagai daerah di Indonesia marak terjadi tindak pidana perdagangan orang, tidak terkecuali di Maluku. Keterbelakangan ekonomi merupakan faktor yang paling dominan dan mempengaruhi terjadinya tindak pidana perdagangan orang.

Berdasarkan angka kemiskinan, Maluku merupakan provinsi termiskin yang menduduki peringkat ke-3 (tiga) di Indonesia setelah Papua dan Papua Barat. Dilain sisi sebagai provinsi berciri kepulauan dengan sumberdaya alam yang melimpah, tidak berbanding lurus dengan taraf ekonomi penduduknya. Hal ini secara jelas dapat digambarkan dalam jumlah penduduk miskin di Maluku berdasarkan Kabupaten/Kota dari tahun 2011- 2016: 
Tabel 1

Jumlah Penduduk Miskin di Maluku Tahun 2011-2016

\begin{tabular}{|l|c||c|c||c|c|c|}
\hline \multirow{2}{*}{ Kabupaten/Kota } & \multicolumn{7}{|c|}{ Jumlah Penduduk Miskin } \\
\cline { 2 - 7 } & 2011 & 2012 & 2013 & 2014 & 2015 & 2016 \\
\hline $\begin{array}{l}\text { Maluku Tenggara } \\
\text { Barat }\end{array}$ & 32.8 & 30.7 & 32.4 & 31.4 & 32.43 & 31.53 \\
\hline \hline Maluku Tenggara & 27.2 & 25.5 & 24.6 & 23.9 & 24.94 & 24.56 \\
\hline \hline Maluku Tengah & 94.1 & 88.1 & 81.4 & 78.9 & 81.43 & 80.28 \\
\hline \hline B u r u & 24.7 & 23.2 & 22.4 & 21.9 & 23.42 & 23.53 \\
\hline \hline Kepulauan Aru & 27.0 & 25.0 & 24.3 & 23.8 & 26.14 & 26.48 \\
\hline \hline Seram Bagian Barat & 45.5 & 42.5 & 41.4 & 40.2 & 44.61 & 45.03 \\
\hline \hline Seram Bagian Timur & 28.6 & 26.9 & 25.8 & 25.1 & 27.44 & 26.89 \\
\hline \hline Maluku Barat Daya & 25.2 & 23.2 & 21.0 & 20.4 & 22.90 & 22.53 \\
\hline Buru Selatan & 10.8 & 10.3 & 9.8 & 9.7 & 10.41 & 10.13 \\
\hline \hline Kota Ambon & 23.4 & 22.0 & 16.9 & 16.9 & 17.94 & 19.64 \\
\hline \hline Kota Tual & 17.1 & 16.0 & 15.0 & 14.8 & 16.74 & 17.12 \\
\hline MALUKU & 356.40 & 333.60 & 315.21 & 307.00 & 328.41 & 327.72 \\
\hline
\end{tabular}

Sumber: Susenas Provinsi Maluku, Update Oktober 2017

Gambaran tabel di atas terlihat menunjukan pernyataan tersebut. Hal ini berimplikasi pada maraknya kejahatan yang sering terjadi di Maluku, salah satunya adalah tindak pidana perdagangan orang.

Berdasarkan pemaparan fakta empiris di atas, maka permasalahan yang hendak dianalisis yaitu Kendala Penanganan Tindak Pidana Perdagangan Orang di Maluku.

\section{METODE PENELITIAN}

Untuk memperoleh informasi dan data-data yang diperlukan guna menjawab permasalahan penelitian ini, maka peneliti menggunakan metode penelitian kualitatif. Sebelum menganalisis secara kualitatif, terlebih dahulu melakukan langkah-langkah sebagai berikut:

\section{Jenis penelitian}

Penelitian sebagai salah satu proses yang dilakukan untuk melengkapi penulisan. Oleh karena itu, pada dasarnya bahwa metode penelitian ini digunakan untuk mendukung penelitian agar benarbenar teruji. Oleh sebab itu, metode merupakan prosedur atau cara untuk mengetahui sesuatu berdasarkan langkah-langkah yang sistematis.

Berdasarkan judul dan permasalahan di atas maka, jenis penelitian yang digunakan dalam penulisan ini adalah yuridis empiris atau yuridis sosiologis. Penelitian ini berbasis pada ilmu hukum normatif (peraturan perundangan), tetapi bukan mengkaji mengenai sistem norma dalam aturan perundangan, namun mengamati bagaiman reaksi dan interaksi yang terjadi ketika sistem norma itu bekerja dalam masyarakat. (ND \& Yulianto, 2010) 


\section{Lokasi penelitian}

Dalam penelitian ini, lokasi yang digunakan sebagai lokasi penelitian adalah Provinsi Maluku. Provinsi Maluku terdiri dari 11 Kabupaten/Kota. Adapun lokasi penelitian yang dipilih oleh peneliti adalah Kota Ambon, Kabupaten Seram Bagian Barat, dan Kabupaten Kepulauan Aru. Lokasi Penelitian dapat dilihat pada peta dibawah ini:

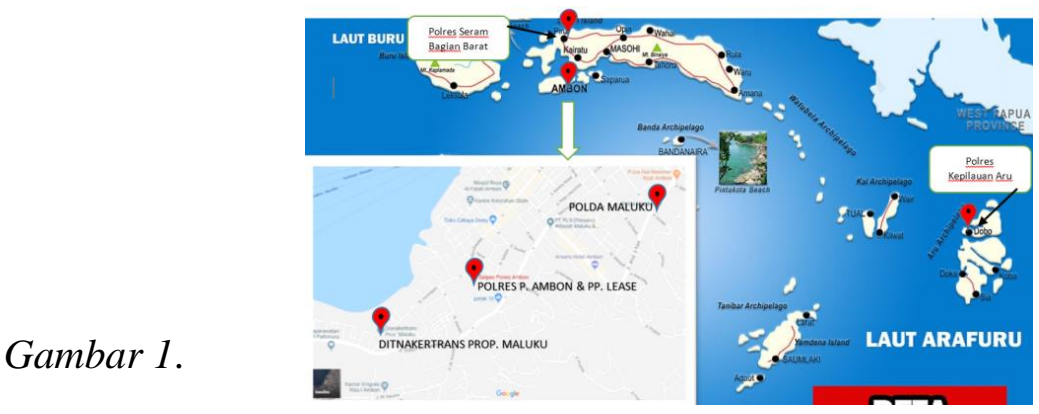

Sumber: $\quad$ https://www.sejarah-negara.com/2017/05/peta-provinsi-maluku-lengkap-9.html,gambar diedit kembali.

\section{Sumber data}

Sumber data yang digunakan pada penulisan ini yaitu : Data Primer dan data sekunder.

1. Data primer adalah : Data yang diterima langsung di lapangan antara lain berupa Wawancara dan observasi. Adapun yang menjadi narasumber adalah penyidik TPPO di Polda Maluku, Polres Kepulauan Aru serta unit PPA (Pelayanan Perempuan dan Anak) Polres Seram Bagian Barat.

2. Data sekunder adalah : Data yang mendukung data primer dan terdiri dari :

a. Bahan Hukum Primer, yaitu : Bahan hukum yang dikeluarkan oleh pemerintah dan bersifat mengikat berupa peraturan perundang-undangan, antara lain :

- Undang-Undang Nomor 21 tahun 2007 tentang Pencegahan dan Pemberantasan Tindak Pidana Perdagangan Orang;

- Undang-Undang Nomor 23 tahun 2002 tentang Perlindungan Anak;

- Undang-Undang Nomor 11 tahun 2009, tentang Kesejahteraan Sosial

b. Bahan Hukum Sekunder : Bahan hukum yang diperoleh dari kepustakaan yang meliputi berbagai literatur maupun sumber-sumber lain berupa makalah, skripsi, tesis, desertasi, serta artikel-artikel lain yang dipublikasikan melalui media cetak dan media elektronik yang berhubungan dengan penelitian ini. (Sunggono, 2003).

c. Bahan Hukum Tersier : Bahan hukum yang memberikan penjelasan terhadap bahan hukum primer dan bahan hukum sekunder diantaranya : Kamus Hukum, Kamus Besar Bahasa Indonesia dan sebagainya.

\section{Teknik pengumpulan data}

Teknik pengumpulan data yang digunakan dalam penelitian ini adalah Pengumpulan data yang diperoleh dan berkaitan dengan masalah yang diteliti diantaranya meliputi : wawancara, observasi dan studi kepustakaan, di mana studi kepustakaan merupakan segala usaha yang dilakukan untuk menghimpun informasi yang relevan dan bahan hukum yang terkait dengan masalah yang dikemukakan

\section{Analisa data}


Dalam penulisan ini, untuk menganalis data dipergunakan analisis kualitatif artinya data yang telah terkumpul atau ditemui harus dipisah-pisahkan menurut kategori masing-masing dan kemudian ditafsirkan dalam usaha mencapai jawaban masalah penulisan ini. Data yang diperoleh dalam penulisan ini. selanjutnya dideskripsikan sesuai dengan pokok-pokok permasalahan yang dikaji secara kualitatif (Soemitro, 1990), untuk menjawab kendala penanganan tindak pidana perdagangan orang di Maluku.

\section{HASIL DAN PEMBAHASAN}

\section{Gambaran umum kesejahteraan sosial di Provinsi Maluku}

Undang-Undang Nomor 11 Tahun 2009, tentang Kesejahteraan Sosial dengan tegas mengamanatkan bahwa "kesejahteraan sosial adalah kondisi terpenuhinya kebutuhan material, spiritual, dan sosial warga Negara agar dapat hidup layak dan mampu mengembangkan diri, sehingga dapat melaksanakan fungsi sosialnya". Karena itu penyelenggaraan kesejahteraan sosial adalah upaya yang terarah, terpadu dan berkelanjutan yang dilakukan pemerintah, pemerintah daerah, dan masyarakat dalam bentuk pelayanan sosial, pemberdayaan sosial, dan perlindungan sosial.

Terkait dengan itu, paradigma kesejahteraan sosial sebagaimana termaktub dalam rumusan Undang-Undang tersebut, mengarahkan pada prinsip-prinsip dasar usaha kesejahteraan sebagai berikut: (Ralahalu, 2005).

1. Setiap warga negara berhak atas kesejahteraan yang sebaik-baiknya dan berkewajiban sebanyak mungkin untuk ikut serta dalam usaha-usaha kesejahteraan sosial;

2. Usaha kesejahteraan merupakan tanggung jawab bersama pemerintah dan masyarakat. Masyarakat mempunyai kesempatan yang seluas-luasnya untuk mengadakan usaha-saha kesejahteraan sosial dengan mengindahkan garis kebijaksanaan dan ketentuan peraturan perundang-undangan di bidang kesejahteraan sosial;

3. Nilai-nilai kemanusiaan, kekeluargaan, kegotongroyongan, kebersamaan, kesetiakawanan sosial, tanggung jawab sosial dan keadilan sosial tercermin dalam usaha kesejahteraan sosial. Kepercayaan akan kemampuan dan harga diri merupakan motivasi dasar, bagi setiap penyandang masalah sosial dengan meniadakan sikap serta watak ketergantungan dan belas kasihan.

Tanggungjawab pemerintah dalam Undang-Undang tersebut tidak sejalan dengan realita yang terjadi, dimana tidak semua daerah memiliki tingkat kesejahteraan yang baik. Hal ini dapat dilihat dari banyak daerah di Indonesia yang penduduknya mempunyai tingkat kesejahteraan yang rendah. Salah satunya adalah provinsi Maluku karena merupakan provinsi termiskin ke-3 (tiga), setelah provinsi Papua dan Provinsi Papua Barat.

Provinsi Maluku secara Geografis terletak diantara $2^{\circ} 30^{\prime}-9^{\circ} \mathrm{LS}$ dan $124^{\circ}-136^{\circ} \mathrm{BT}$, dengan batas-batas adminitrasi sebagai berikut :

- Sebelah Utara : Provinsi Maluku Utara;

- Sebelah Selatan : Negara Timor Leste dan Australia;

- Sebelah Timur : Provinsi Papua;

- Sebelah Barat : Provinsi Sulawesi Tenggara dan Sulawesi Tengah.

Provinsi Maluku merupakan provinsi kepulauan yang memiliki luas wilayah $581.376 \mathrm{~km}^{2}$, terdiri dari $527.191 \mathrm{~km}^{2}(90,68 \%)$ wilayah perairan dan $54.185 \mathrm{~km}^{2}$ wilayah daratan $(9,32 \%)$. Luas daratan ini merupakan gabungan daratan pulau-pulau besar dan kecil. Jumlah pulau di Maluku sebanyak 559 pulau. Menurut Undang-Undang Nomor 27 tahun 2007 pasal 3, pulau kecil adalah 
pulau dengan luas lebih kecil atau sama dengan $2000 \mathrm{~km}^{2}$ beserta kesatuan ekosistemnya. Didasarkan pada defenisi tersebut, maka di Maluku hanya terdapat 4 (empat) pulau besar yaitu : Pulau Seram (18.625 km²), Pulau Buru $\left(9000 \mathrm{~km}^{2}\right)$, Pulau Yamdena $\left(5.085 \mathrm{~km}^{2}\right)$, dan Pulau Wetar $\left(3.624 \mathrm{~km}^{2}\right)$. Selain 4 (empat) pulau tersebut seluruh pulau di Maluku termasuk pulau kecil.

\section{Kendala penanganan tindak pidana perdagangan orang di Maluku}

Penegakan hukum merupakan salah satu usaha untuk menciptakan tata tertib, keamanan, keharmonisan dan ketenteraman dalam masyarakat, baik itu merupakan usaha pencegahan maupun pemberantasan atau penindakan setelah terjadinya pelanggaran hukum (baik secara preventif maupun represif). Hukum hadir memberikan perlindungan terhadap hak-hak asasi warga negara dari kemungkinan adanya pelanggaran dalam penggunaan kewenangan tersebut (Rahardjo, 2009).

Selaku penegak hukum, polisi wajib melakukan penegakan hukum terkait dengan tindak pidana yang terjadi di wilayah hukumnya, tidak terkecuali dengan tindak pidana yang dilakukan di Maluku salah satunya tindak pidana perdagangan orang. Secara konseptual perdagangan orang dapat dipahami sebagai suatu aktifitas yang meliputi proses perekrutan, pengangkatan, pemindahan, penampungan, atau penerimaan seseorang dengan ancaman atau penggunaan kekerasan atau bentuk-bentuk pemaksaan lainnya, yaitu penculikan, pemalsuan, penipuan, penyalahgunaan kekuasaan atau posisi ataupun memberi atau menerima bayaran serta manfaat tertentu sehingga memperoleh persetujuan dari orang-orang yang memegang kendali atas orang lain yang rentan tereksploitasi. Berdasarkan hasil penelitian ini, didapati dari tahun 2014-2017 telah terjadi beberapa kasus tindak pidana perdagangan orang, yang penulis sajikan didalam tabel berikut ini :

Tabel 2. Data-Data Kasus TPPO Yang Ditangani Oleh Kepolisian Wilayah Maluku tahun 2014-

\begin{tabular}{|c|l|c|c|c|c|c|}
\hline \multirow{2}{*}{ No } & \multicolumn{1}{|c|}{ Instansi } & \multicolumn{3}{|c|}{ Jumlah Kasus/Tahun } & \multirow{2}{*}{ Jumlah } \\
\cline { 2 - 6 } & \multicolumn{2}{|c|}{$\mathbf{2 0 1 4}$} & $\mathbf{2 0 1 5}$ & $\mathbf{2 0 1 6}$ & $\mathbf{2 0 1 7}$ & $\mathbf{2}$ \\
\hline $\mathbf{1}$ & Polda Maluku & $\mathbf{1}$ & - & $\mathbf{2}$ & $\mathbf{2}$ & $\mathbf{5}$ \\
\hline $\mathbf{2}$ & $\begin{array}{l}\text { Polres P. Ambon dan P.P } \\
\text { Lease }\end{array}$ & - & $\mathbf{1}$ & - & - & $\mathbf{1}$ \\
\hline $\mathbf{3}$ & Polres Kepulauan Aru & - & $\mathbf{1}$ & - & - & $\mathbf{1}$ \\
\hline $\mathbf{4}$ & Polres Seram Bagian Barat & - & - & - & - & NIHIL \\
\hline $\mathbf{5}$ & Polres Seram Bagian Timur & - & - & - & - & NIHIL \\
\hline $\mathbf{6}$ & Polres Maluku Tengah & - & - & - & - & NIHIL \\
\hline
\end{tabular}

\section{Sumber : Polda Maluku}

Dari tabel di atas, akan dijabarkan secara singkat beberapa kasus 3 tahun terakhir sebagai berikut:

- Pada tahun 2016, Polda Maluku menangani 2 (dua) kasus. Kasus pertama penanganannya didasari dengan laporan polisi : LP-B/136/IV/2016/SPKT, tanggal 7 April 2016. Dengan tersangka D.S, S.A, dengan korban 7 (tujuh) orang yang berumur 15-17 tahun. Para korban dibawa dari Makasar oleh S.A dengan tujuan untuk bekerja sebagai pramusaji di wisma dan biaya perjalanan para korban ditanggung oleh D.S. D.S menerima para korban dan mempekerjakan para korban sebagai PSK di wisma anggrek Batu Merah. Kasus ke-dua penanganannya didasari dengan laporan polisi: LP-A/ 334/XI/2016/SPKT, tanggal 11 
November 2016. Dengan tersangka J.G, dan kawan-kawan, dengan korban 11 orang laki-laki dewasa. Pada hari selasa tanggal 25 Oktober 2016 telah terjadi tindak pidana pembunuhan yang mengakibatkan ABK dari kapal sinar bahari 11 meninggal dunia di PPI desa ureng, kecamatan Leihitu, Kabupaten Maluku Tengah. Kemudian pada tanggal 7 Oktober 2016 Direktur Reserse Kriminal Umum Polda Maluku memerintahkan untuk melakukan penyelidikan terhadap kasus identitas dari korban yang meninggal dan merupakan warga Filiphina dan para ABK Sinar Bahari 11 lainnya merupakan WNA Filiphina yang diduga korban TPPO. Mereka direkrut dari Bitung tanpa identitas yang jelas kemudian dibuatkan dokumen SEAMAN's BOOK palsu dan dipekerjakan di atas kapal.

- Pada tahun 2017, Polda Maluku menangani 2 (dua) kasus. Kasus I (pertama), penanganannya didasari dengan laporan polisi : LP-B/25/I/2017/SPKT, tanggal 24 Januari 2017. Dengan tersangka R.P, M.A, L.K, Z.K. korban E.F.L berumur 16 tahun. Korban TPPO direkrut oleh R.P untuk bekerja sebagai pelayan di swalayan di Negara Malaysia kemudian korban dijemput oleh M.A dengan janji akan diajak untuk bekerja sebagai pembantu rumah tangga di Malaysia. Korban dibawa ke rumah tersangka L.K dan diberangkatkan ke Jakarta, ditampung di rumah tersangka Z.K kemudian korban diberangkatkan ke Malaysia dan dipekerjakan dengan memperoleh gaji sebesar 800 ringgit Malaysia sambil menunggu dibuatkan paspor dan dokumen lainnya. Kasus II (dua) penanganannya didasarkan pada laporan polisi : LPB/301/IX/2017/SPKT, tanggal 04 September 2017. Dengan tersangka H.R Cs, dan korban S.D.S berumur 16 tahun. Korban perdagangan orang dibawah dari Makasar oleh H.R dengan tujuan untuk bekerja sebagai pramusaji di kafe 77 Bula, kabupaten Seram Bagian Timur ditanggung oleh pemilik kafe dan mempekerjakan korban sebagai PSK.

- Pada tahun 2015, Polres Kepulauan Aru menangani 1 (satu) kasus. Penanganannya didasari dengan Laporan Polisi : LP 16/III/2015/RES ARU, Tanggl 03 Maret 2015. Dengan 8 (delapan) tersangka, yaitu HP (WN Thailand), BJ (WN Thailand), SM (WN Thailand), SK (WN Thailand), YN (WN Thailand), M (WNI), Y (WNI), dan H (WNI). korban sebanyak 28 orang (semuanya WN Myanmar).

Berdasarkan kasus-kasus di atas, yang sangat mendapat perhatian secara nasional maupun internasional yaitu kasus TPPO yang terjadi di Desa Benjina Kecamatan Aru Tengah Kabupaten Kepulauan Aru Provinsi Maluku, karena pelaku TPPO bukan hanya melibatkan warga Negara Indonesia, tetapi juga melibatkan WNA yakni Thailand. Selain itu semua korban berjumlah 28 (dua puluh delapan) orang merupakan WN Myanmar.

Presiden Republik Indonesia Joko Widodo, pada saat itu langsung menginstruksikan kepada para penegak hukum untuk segera menyelesaikan kasus ini. Berdasarkan proses penyidikan, penuntutan sampai dengan pemeriksaan perkara di muka Pengadilan Negeri Tual, didapati bahwasanya ke-8 (delapan) terdakwa, masing-masing 3 (tiga) orang WNI dan 5 (lima) orang WN Thailand secara sah dan meyakinkan berdasarkan putusan hakim dinyatakan bersalah melakukan tindak pidana perdagangan orang dan masing-masing terdakwa dijatuhi pidana penjara 3 (Tiga) tahun dan denda Rp.160.000.000,- (seratus enam puluh juta rupiah). Selain itu juga diantara terdakwa ada yang dibebani untuk membayar restitusi kepada para korban TPPO tersebut.

Maluku sebagai provinsi berciri kepulauan menjadi daerah terbuka yang sangat membuka peluang maraknya tindak pidana perdagangan orang. Disamping itu rentang kendali yang jauh dengan pulau-pulau perbatasan, sumber daya alam yang melimpah menjadi daya tarik orang bekerja baik secara legal maupun illegal. Hal tersebut menjadi peluang maraknya kasus tindak pidana perdagangan orang,

Kasus-kasus yang digambarkan di atas terlihat bahwa pada umumnya, modus operandi yang dilakukan pelaku untuk melakukan tindak pidana ini yaitu, penipuan dengan korban dijanjikan pemberian pekerjaan yang bagus dan diberikan iming-iming mendapatkan upah 
yang besar. Latar belakang ekonomi yang miskin, tingkat pengetahuan yang kurang merupakan penyebab dengan mudahnya korban dapat dipengaruhi oleh pelaku TPPO untuk diekspolitasi jasanya sehingga pelaku mendapatkan keutungan yang sebesar-besarnya. Disisi lain penanganan kasus TPPO membutuhkan sarana dan prasarana yang memadai karena Maluku merupakan daerah kepulauan dengan rentang kendali yang cukup jauh apabila ditemukan kasus-kasus tersebut di daerah terpencil.

Terkait dengan penanganan tindak pidana perdagangan orang di Maluku, institusi kepolisian menggunakan Undang-Undang Nomor 21 Tahun 2007 tentang Pemberantasan Tindak Pidana Perdagangan Orang, selain itu juga kerap digunakan Undang-Undang Nomor 23 Tahun 2002 tentang perlindungan anak, karena selain korban merupakan orang dewasa, didapati juga anak-anak.

Praktik perdagangan orang di Maluku, dalam penegakan hukumnya terdapat beberapa kendala, yaitu :

1. Budaya konsumtif dan hedonisme di masyarakat: Hal ini berimplikasi pada pada keinginan untuk mendapatkan sesuatu secara instan dan mudah.

2. Kemajuan Teknologi dan Informasi: Hal ini dimanfaatkan oleh pelaku TPPO (trafficker) untuk mencari korbannya dengan berbagai cara.

3. Adanya bekingan oleh segelintir orang yang memiliki kekuasaan: Tidak dapat dipungkiri, bahwa kekuasaan seringkali disalahgunakan untuk kepentingan sekelompok orang tertentu. Hal ini juga kerap kali ditemui pada proses pemeriksaan TPPO di beberapa wilayah hukum Maluku.

4. Ketersediaan rumah singgah bagi korban TPPO belum merata di Wilayah Maluku: Hal ini merupakan realita yang ditemui, sehingga untuk mensiasatinya seringkali penegak hukum dalam hal ini polisi menggunakan tempat-tempat tertentu sebagai tempat penampungan sementara bagi korban TPPO, diantaranya mes Polwan.

5. Terbatasnya Anggaran: Terbatasnya anggaran penyidikan korban maupun tersangka/terdakwa yang notabenenya merupakan WNA, disamping kendala bahasa (kebutuhan penerjemah/ahli bahasa). Hal tersebut terkait dengan rentang kendali wilayah Maluku sehingga untuk mendatangkan juru bahasa/penerjemah membutuhkan waktu dan coast yang besar, selain terbatasnya anggaran yang disediakan pemerintah daerah untuk memulangkan korban TPPO ke daerah/Negara asalnya.

6. Minimnya pemahaman masyarakat tentang TPPO: yang miris ditemui bahwasanya ada peran orang tua yang turut untuk memalsukan umur anaknya di kartu identitas diri (KTP), sebagai salah satu syarat adminitrasi yang dipenuhi untuk pelaku TPPO mempekerjakan mereka. Peluang ini sering dimanfaatkan oleh pelaku TPPO untuk melakukan aksinya

Selain kendala-kendala yang ditemui dalam penegakan hukum TPPO di Maluku, sebenarnya sudah ada langkah awal Polisi wilayah Maluku, khususnya di Polres Seram Bagian Barat yang patut diberikan apresiasi dan perlu ditingkatkan dalam penanganan tindak pidana perdagangan orang khususnya terhadap anak, dimana setiap tahunnya melakukan identifikasi umur pekerja di tempat hiburan malam yang terletak di kairatu barat tepatnya di desa waisarisa. Hal ini dilakukan oleh tim identifikasi Polres Seram Bagian Barat untuk meminimalisir tindak pidana tersebut yang dominan korbannya adalah anak-anak. Hal yang sama juga dilakukan oleh Polda Maluku dalam kurun waktu tertentu menggelar penertiban di lokalisasi tanjung batu merah. Tindakan tersebut berhasil mengamankan 7 (tujuh) perempuan dibawah umur. Kemudian diambil alih oleh Dinas Sosial Maluku untuk diberikan pembinaan dan dipulangkan ke daerah mereka yaitu Sulawesi Tenggara. 


\section{KESIMPULAN DAN SARAN}

Berdasarkan hasil penelitian yang telah dipaparkan sebelumnya ditemui bahwa kendala-kendala dalam penegakan hukum tindak pidana perdagangan orang di Maluku yaitu Budaya konsumtif dan hedonisme di masyarakat, Kemajuan Teknologi dan Informasi, Adanya bekingan oleh segelintir orang yang memiliki kekuasaan, Ketersediaan rumah singgah bagi korban TPPO belum merata di Wilayah Maluku, Ketersediaan biaya pemulangan korban TPPO ke daerah asal belum merata, terbatasnya anggaran, minimya pemahaman masyarakat tentang TPPO. Mengingat Maluku sebagai daerah kepulauan, untuk itu disarankan perlu adanya koordinasi yang baik antara dinasdinas terkait dalam hal ini, kepolisian, pemerintah pusat, pemerintah daerah, dinas sosial, dinas ketenagakerjaan serta stakeholder lainnya guna melakukan pengawasan yang intens terhadap perempuan dan anak yang seringkali menjadi korban TPPO disamping perlunya penyediaan fasilitas penampungan sementara untuk korban TPPO secara merata di seluruh wilayah Maluku.

\section{Ucapan Terima Kasih}

Penelitian ini dapat diselesaikan dengan atas peran berbagai pihak, olehnya itu penulis menyampaikan terima kasih kepada Pimpinan Universitas Pattimura atas bantuan dana yang diberikan, Penyidik Polda Maluku, Polres SBB dan Polres Kepulauan Aru atas bantuan data yang diberikan.

\section{REFERENSI}

Arief, B. N. (2010). Bunga Rampai Kebijakan Hukum Pidana. Bandung: Citra Aditya Bakti.

Farhana. (2010). Aspek Hukum perdagangan orang di Indonesia. Jakarta: Sinar Grafika.

Hardum, S. E. (2016). Perdagangan manusia berkedok pengiriman TKI. Yogyakarta: Ar-Ruzz Media.

Heni, S. (2013). Telaah Kritis: Kegagalan Penegakan Hukum Pidana Kejahatan Perdagangan Orang. Masalah-Masalah Hukum, 463-472.

Indonesia-IOM. (2009). Pedoman penegakan hukum dan perlindungan korban dalam penanganan TPPO. Jakarta: IOM Indonesia.

Muladi, \& Arief, B. N. (2010). Teori-teori dan kebijakan pidana. Bandung: Alumni.

Munthe, R. (2015). Perdagangan Orang (Trafficking) Sebagai Pelanggaran Hak Asasi Manusia. Jurnal Pendidikan Ilmu-Ilmu Sosial, 184-192.

ND, M. F., \& Yulianto, A. (2010). Dualisme penelitian hukum normatif dan empiris. Yogyakarta: Pustaka Pelajar.

NGO. (2005). Penghapusan Perdagangan orang di indonesia. jakarta: Kementerian Koordinator Bidang Kesejahteraan Rakyat.

Rahardjo, S. (2009). Penegakan hukum suatu tinjauan sosiologis. Yogyakarta: Genta Publishing.

Ralahalu, A. K. (2005). Berlayar Dalam Ombak: Barkarya Bagi Negeri (Pemikiran Anak Negeri Bagi Maluku). Ambon: Ralahalu Institut.

Soemitro, R. H. (1990). Metodologi penelitian hukum dan jurimetri. Jakarta: Ghalia Indonesia.

Sunggono, B. (2003). Metode penelitian hukum. Jakarta: Raja Grafindo Persada. 